\title{
Induction of Mitotic Arrest and Apoptosis by Diallyl Trisulfide in U937 Human Leukemia Cells
}

\author{
Hyun Soo Park', Jun Hyuk Lee ${ }^{2}$, Byoung Yil Son ${ }^{3}$, Byung Tae Choi ${ }^{1}$ and Yung Hyun Choi ${ }^{4,{ }_{*}}{ }_{\star}$ \\ ${ }^{1}$ School of Korean Medicine, Busan National University, Yangsan 626-870, Korea \\ ${ }^{2}$ Biotechndogy Examination Division, Chemistry and Biotechnology Examination Bureau, Korean Intellectual Property Office, Dagieon 302-701, \\ Korea \\ ${ }^{3}$ Blue-Bio Industry Regional Innovation Center \& 4Anti-Aging Research Center \& Dongeui University, Busan 614-714, Korea \\ ${ }^{5}$ Department of Biochemistry, Dongeui University College of Oriental Medicine, Busan 614-052, Korea
}

Received March 7, 2013 /Revised March 14, 2013 /Accepted March 22, 2013

\begin{abstract}
Diallyl trisulfide (DATS), one of the major organosulfur components of garlic (Allium sativum), has various biological effects such as anti-microbial and anti-cancer activities. However, the molecular mechanisms of growth inhibition related to cell cycle arrest are poorly understood. In this study, we investigated the effects of DATS on cell cycle progression in U937 human leukemia cells. Treatment with DATS in U937 cells resulted in inhibition of cell viability through G2/M arrest and apoptosis. DATS-induced G2/M arrest was associated with up-regulation of cyclin B1 and cyclin-dependent kinase 1 (CDK1). DATS also significantly increased levels of phospho-histone H3, which is a mitosis-specific marker, indicating that DATS induced mitotic arrest but not G2 arrest in U937 cells. DATS treatment also generated the reactive oxygen species (ROS) in U937 cells; however, pretreatment with $\mathrm{N}$-acetyl-1-cysteine (NAC), a ROS scavenger, significantly attenuated DATS-induced mitotic arrest and apoptosis. Taken together, our data indicate that DATS exhibits anti-cancer effects through mitotic arrest and apoptosis in a ROS-dependent manner.
\end{abstract}

Key words : Diallyl trisulfide, mitotic arrest, apoptosis, reactive oxygen species (ROS)

\section{서 론}

전 세계 주요 사망원인 중 하나인 암은 세포의 증식과 사멸 을 조절하는 유전자의 돌연변이가 축적된 결과로 일어나고, 결과적으로 세포의 무분별한 증식으로 인해 야기되는 질병이 다[6]. 특히 혈구암은 혈액 혹은 골수에 발병하는 암으로 백혈 구의 비정상적인 증식을 초래하게 된다. 이런 혈구암은 임상 및 병리학적인 소견으로 급성 및 만성 혈구암으로 구분된다. 급성 혈구암의 경우 어린이 혹은 젊은 층에서 주로 발병하고, 만성 혈구암의 경우 주로 나이가 많은 사람들에게서 발병하는 것으로 알려져 있다[1, 11]. 혈구암은 치료가 어렵고 재발의 확률이 높은 암으로서 보다 더 효과적인 생리활성을 가진 물 질을 찾고 그 기전을 밝히는 것이 중요하다고 할 수 있다. 오랫동안 요리의 재료와 의약적인 목적으로 많이 이용되고 있는 마늘(Allium sativum)에는 다양한 유황화합물을 함유하 고 있으며 그 중에서 diallyl sulfide (DAS), diallyl disulfide

\section{*Corresponding author}

Tel : +82-51-850-7413, Fax : +82-51-853-4036

E-mail : choiyh@deu.ac.kr

This is an Open-Access article distributed under the terms of the Creative Commons Attribution Non-Commercial License (http://creativecommons.org/licenses/by-nc/3.0) which permits unrestricted non-commercial use, distribution, and reproduction in any medium, provided the original work is properly cited.
(DADS), diallyl trisulfide (DATS)와 같은 지용성 유기황화합 물이 강력한 항암효과를 가지고 있다고 알려져 있다[10, 25, 26]. 특히, 한 분자에 세 개의 황을 함유하고 있는 DATS가 $\mathrm{DAS}$ 또는 DADS에 비해 항암 및 항염증 효과와 같은 생물학 적인 효과를 더 강하게 나타낸다고 보고되고 있다 $[13,18,21]$. DATS가 다양한 암세포주에서 자가세포사멸(apoptosis) 및 세 포주기 교란(cell cycle arrest) 유발을 통하여 세포의 증식을 억제한다고 알려져 있지만[4,5,21] 인체 혈구암세포에서 세포 증식 억제 현상에 대해서는 정확한 기전이 밝혀져 있지 않다.

세포분열 중, 유사분열기(M기)에서 문제가 일어나는 현상 은 중심체 또는 방추사의 결함으로 종종 야기된다. 그 결과, mitotic arrest가 일어나 새로운 세포주기로 진입하지 못하고 결국 apoptosis가 유도된다. 최근에 보고된 바에 의하면, 손상 된 DNA에 의하여 중심체가 불활성화 되고, 비정상적인 방추 사 형성 및 염색체 미분리 현상이 일어나 mitotic arrest 및 비정상적인 유사분열이 유도된다고 알려져 있다 $[8,16]$. Mitotic arrest를 유도하는 분자기전은 G2기에서 유사분열기 로 이행하는데 핵심적인 역할을 하는 cyclin-dependent protein kinase 1 (CDK1)과 cyclin B와 관련이 있다. 일반적으로 $\mathrm{G} 2$ 기에서 증가된 cyclin B1의 발현이 유사분열기에서 감소해 야 G1기로 이행한다고 알려져 있다. 하지만 유사분열기에서 cyclin B1의 발현량이 감소하지 않고 축적되어 있을 경우 유사 분열기에서 G1기로 빠져나가지 못해 mitotic arrest가 일어난 
다. 추가적으로 $\mathrm{CDK} 1$ 의 계속적인 활성화가 유지될 경우에도 mitotic arrest가 일어난다. 또한 CDK1은 anti-apoptotic Bcl-2 단백질을 인산화시켜 미토콘드리아의 기능을 손상시켜 apoptosis를 유도한다고 알려져 있다[19, 29].

본 연구에서는 DATS의 항암효과에 관한 생화학적인 기전 을 밝히기 위하여 U937 인체 혈구암세포주에서의 증식억제 정도와 세포주기조절과 관련된 단백질 발현 변화를 조사하여 유의적인 결과를 얻었기에 이를 보고하고자 한다.

\section{재료 및 방법}

\section{실험 재료}

본 실험에 사용된 DATS는 LKT Laboratories (St. Paul, $\mathrm{MN}, \mathrm{USA}$ )에서 구입하였으며 dimethyl sulfoxide (DMSO)에 $100 \mathrm{mM}$ 농도로 녹여 사용하였다. 증식 억제 정도를 측정하기 위한 3-(4,5-Dimethylthiazol-2-yl)-2,5-diphenyltetrazolium bromide (MTT)와 세포 내 생성된 활성산소종(reactive oxygen species, ROS)을 억제하기 위한 N-acetyl-1-cysteine (NAC)은 Sigma-Aldrich Chemical Co. (St. Louis, MO, USA) 에서 구입하였다. 단백질 발현 분석을 위한 Western blotting 에 사용된 1차 및 2차 항체는 모두 Santa Cruz Biotechnology (Santa Cruz, CA, USA)에서 구입하였다.

\section{세포 배양 및 MTT assay}

실험에 사용한 인체혈구암 U937세포는 American Type Culture Collection (Rockville, MD, USA)에서 분주 받아 10\% 의 우태아혈청(fetal vovine serum, FBS) 및 $1 \%$ 의 penicillin 및 streptomycin이 포함된 RPMI-1640 배지(Gibco-BRL, Grand Island, $\mathrm{NY}, \mathrm{USA}$ )를 사용하여 $37^{\circ} \mathrm{C}, 5 \% \mathrm{CO}_{2}$ 조건 하에 서 배양하였다. DATS 처리에 따른 세포증식 억제 정도를 측정 하기 위하여 6 well plate에 U937 세포를 well당 $2 \times 10^{5}$ 개를 분주하고 DATS를 적정농도로 처리시간을 달리하여 배양하였 다. 그 후 MTT 시약을 $0.5 \mathrm{mg} / \mathrm{ml}$ 농도로 2시간 동안 배양 후, 배지를 제거하고 $\mathrm{DMSO}$ 를 $2 \mathrm{ml}$ 씩 분주하여 well에 생성된 formazan을 모두 녹인 후 ELISA reader (Molecular Devices, Sunnyvale, CA, USA)로 $540 \mathrm{~nm}$ 에서 흡광도를 측정하였다.

\section{세포주기와 apoptosis 정량화 및 ROS 측정을 위한 flow cytometry 분석 \\ 세포주기 분석을 위한 세포는 phosphate buffered saline} (PBS)로 충분히 수세 하고 CycleTEST Plus DNA Reagent Kit (Becton Dickison, San Jose, CA, USA)를 사용하여 고정 및 propidium iodide (PI) 처리하여 $4{ }^{\circ} \mathrm{C}$, 암조건에서 10 분 이상 염색 시켰다. 염색된 세포를 25-mm mesh를 이용하여 단일세 포로 분리한 후 FACSCallibur (Becton Dickison)를 이용하여 형 광반응에 따른 cellular DNA content 및 histogram을 Cell
Quest software 프로그램을 이용하여 분석하였다. Apoptosis 가 일어난 정도를 분석하기 위한 세포는 PBS로 2 번 수세 하고 $1 \mathrm{x}$ binding buffer를 넣어준 후 annexin V-FITC를 처리하여 암상태의 실온에서 20분간 염색 후 FACSCallibur를 이용하여 분석하였다. DATS를 시간별로 처리한 U937 세포 내의 ROS 양을 측정하기 위해서는 $10 \mu \mathrm{M}$ Dichlorofluorescin diacetate (DCFDA)로 염색시키고 $37^{\circ} \mathrm{C}, \mathrm{CO}_{2}$ incubator에서 30 분간 반 응시켰다. 그 후 세포를 모으고 PBS로 수세 후 FACSCallibur 를 이용하여 세포 내 ROS 양을 측정하였다.

\section{DNA fragmentation 분석}

Apoptosis가 일어날 때 나타나는 DNA의 분절화 현상을 관찰하기 위하여 DATS를 농도별로 처리한 후 세포를 모아 lysis buffer [5 mM Tris-HCl (pH 7.5), 5 mM EDTA, 0.5\% Triton X-100]를 $4^{\circ} \mathrm{C}$ 에서 30 분간 처리하고 원심분리 후 상층 액을 모은 다음, proteinase K (Sigma-Aldrich)를 $0.5 \mathrm{mg} / \mathrm{ml}$ 의 농도로 처리하고 $50^{\circ} \mathrm{C}$ 에서 3 시간 동안 반응시켰다. 그 후 phenol : chloroform : isoamyl alcohol 혼합용액(25: $24: 1$, Sigma-Aldrich)을 첨가하여 30 분간 inverting 한 뒤 원심분 리하여 상층액을 분리하고 isopropanol (Sigma-Aldrich)과 5 $\mathrm{M} \mathrm{NaCl}$ 을 첨가한 다음 $4^{\circ} \mathrm{C}$ 에서 overnight시켰다. 그 후 원 심분리를 이용하여 pellet을 분리하고 $70 \%$ 에탄올로 충분히 세척하고 RNase A가 적당량 들어있는 D.W.에 녹여 gel loading dye (Bioneer, Daejeon, Korea)를 혼합한 후 1.5\% agarose gel에 1시간 정도 $50 \mathrm{~V}$ 로 전기영동한 후 ethidium bromide (EtBr, Sigma-Aldrich)로 염색하여 ultra violet (UV) 하에서 관찰하였다.

\section{단백질 분리, 전기영동 및 Western blot analysis}

준비된 세포들을 모아 PBS로 씻어내고 적당량의 lysis buffer [25 mM Tris-Cl (pH 7.5), $250 \mathrm{mM} \mathrm{NaCl}, 5 \mathrm{mM}$ EDTA, $1 \%$ NP-40, 1 mM phenylmethylsulfonyl fluoride (PMSF), 5 $\mathrm{mM}$ dithiothreitol (DTT)]를 첨가하여 $4^{\circ} \mathrm{C}$ 에서 1 시간 반응 시킨 후, $14,000 \mathrm{rpm}$ 으로 30 분간 원심분리하여 그 상층액을 모았다. 상층액의 단백질 농도를 Bio-Rad 단백질 정량시약 (Bio-Rad, Hercules, CA, USA)을 사용하여 정량한 다음 동량 의 Laemmli sample buffer (Bio-Rad)를 섞어 sample을 만들었 다. 이렇게 만든 동량의 단백질을 sodium dodecyl sulphate (SDS)-polyacrylamide gel을 이용하여 전기영동으로 분리하 였다. 분리된 단백질을 함유한 acrylamide gel을 nitrocellulose membrane (Schleicher and Schuell, Keene, NH, $\mathrm{USA})$ 으로 전이시킨 후, $5 \% \mathrm{skim}$ milk를 함유한 PBS-T $(0.1 \%$ Tween 20 in PBS)를 처리하여 비특이적인 단백질에 대해 blocking을 실시하였다. 준비된 membrane에 1차 항체를 처리 하여 $4^{\circ} \mathrm{C}$ 에서 overnight 하고 PBS-T로 세척한 후 2차 항체를 사용하여 실온에서 1 시간 정도 반응시켰다. 다시 PBS-T를 이 
용하여 세척하고 enhanced chemiluminescence (ECL) 용액 (Amersham Life Science Corp., Arlignton Heights, IL, USA) 을 처리하여 특정단백질 양을 분석하였다.

\section{결과 및 고찰}

\section{DATS 처리에 의한 U937 세포의 증식 억제}

DATS가 U937 인체 혈구암세포 증식에 미치는 영향을 알아 보기 위하여 적정농도의 DATS를 시간별로 처리하여 배양한 다음 MTT assay를 실시한 결과는 Fig. $1 \mathrm{~A}$ 에 나타난 바와 같 다. DATS 처리농도와 시간경과에 따라 U937 세포의 증식이 억제되어 12 시간 처리군의 경우 대조군에 비하여 $20 \mu \mathrm{M}$ 및 $30 \mu \mathrm{M}$ 농도에서 각각 $40 \%$ 및 $50 \%$ 이상의 증식억제 효과를 보였다. 이러한 세포증식 억제 효과는 flow cytometer를 이용 한 세포주기분석을 통해서도 확인할 수 있었는데 apoptotis가 일어난 세포의 빈도를 의미하는 sub-G1기 속하는 세포의 빈도 가 DATS 처리 시간이 길어질수록 크게 증가 했을 뿐 아니라 $\mathrm{G} 2 / \mathrm{M}$ 기의 세포 빈도 역시 크게 증가함을 알 수 있었다(Fig. 1B). 이는 DATS에 의한 U937 인체혈구암세포의 증식억제는 apoptotis와 $\mathrm{G} 2 / \mathrm{M}$ arrest 유발과 연관되어 있음을 의미하는 결과이다.

\section{DATS 처리에 의한 apoptosis 유발}

세포의 죽음은 크게 apoptosis와 necrosis로 구분될 수 있으 며, 이는 세포의 형태 및 생화학적 특성에 의해 구별된다. 세포 가 팽창함으로써 세포막이 파괴되고 세포 내의 내용물이 세포 외로 유출되어 염증을 일으키는 necrosis와는 달리 apoptosis 는 유전자에 의해 제어됨으로써 능동적으로 죽게 된다. 이런 apoptosis는 세포막의 파괴, 세포질 및 염색질 응축, DNA의 규칙적인 절단 등의 현상이 일어나며, 생체의 발생 및 항상성 유지에 중요하게 작용한다 $[9,24]$. DATS가 U937세포에서 증 식억제를 일으키는 것이 apoptosis 유도 현상과 연관성을 지 니는지 재확인하기 위해 apoptosis의 특이적인 현상인 DNA 절편화 여부를 관찰하였다. 이를 위해 DATS를 다양한 농도로 처리하고 12시간 배양한 U937세포를 모아 DNA를 분리하여 DNA fragmentation assay를 수행한 결과 Fig. $2 \mathrm{~A}$ 와 같이 DATS처리 농도의존적 절편화 현상을 확인할 수 있었다. 또한 apoptosis가 일어날 때 세포막의 인지질 이중층 중 안쪽에 위 치한 phosphatidyl serine이 바깥쪽으로 이동하게 되는데 이 것을 표지하는 염색시약인 Annexin V를 사용하여 apoptosis 유무를 정량적으로 확인한 결과, DATS처리 농도 의존적으로 apoptosis가 유도된 세포의 빈도가 크게 증가하였음을 관찰할 수 있었다(Fig. 2B). 그리고 apoptosis 유도의 분자적 marker인 poly(ADP-ribose)polymerase (PARP) 단백질의 단편화 또한 DATS처리 농도 의존적으로 증가되었음을 알 수 있었다(Fig. 2C). 이러한 결과들은 DATS 처리에 의한 U937 세포의 증식
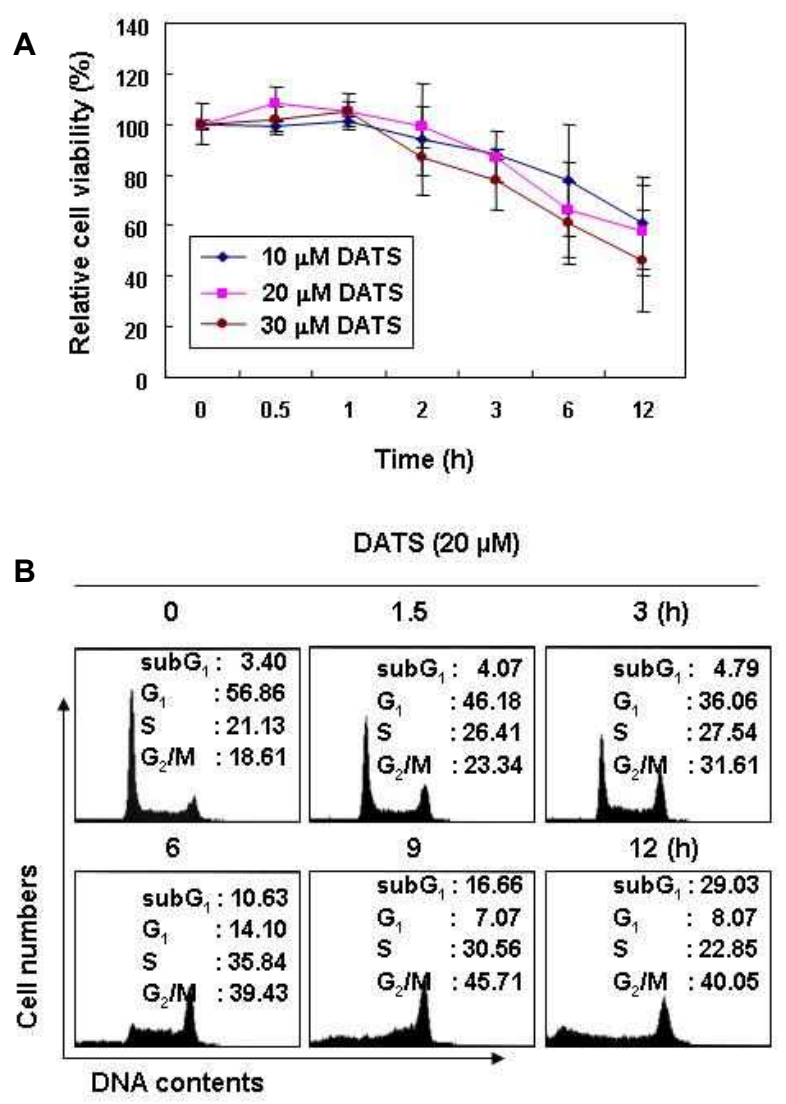

Fig. 1. Inhibition of cell proliferation by DATS treatment in U937 cells. Cells were seeded in 6-well plates at an initial density of $2 \times 10^{5}$ cells per well and treated with indicated concentrations of DATS for various periods. (A) The growth inhibition was measured by MTT assay. Results are expressed as percentage of the vehicle treated control $\pm S D$ of three separate experiments. (B) The cell cycle distribution was analyzed by flow cytometry. Cells were collected and 10,000 events were analyzed for each sample. The results are expressed as the mean $₫ \mathrm{SD}$ of two independent experiments.

억제가 apoptosis 유도와 밀접한 관련이 있음을 보여주는 것 이다.

\section{DATS 처리에 의한 mitotic arrest 유발}

세포주기의 진행 조절은 각 주기별 다양한 단백질 조절인자 들에 의해 복잡하게 조절되는데, 그 중에서 $\mathrm{CDK}$ 가 세포주기 의 진행에 있어서 핵심적인 조절인자로 알려져 있다. 세포주 기 중 $\mathrm{G} 2$ 기에 작용하는 $\mathrm{CDK} 1$ 과 cyclin B는 G2기에서 $\mathrm{M}$ 기로 의 진행과정에서 핵심적인 역할을 하는 조절단백질이다[14, $17,20]$. 하지만 cyclin B1 발현이 다시 $\mathrm{M}$ 기에서 감소해야만 유사분열단계를 마무리 짓고 G1기로 넘어가지만 cyclin B1이 축적되면 $\mathrm{M}$ 기를 빠져나가지 못하게 된다[3]. 또한 $\mathrm{CDK} 1$ 의 과도한 활성화가 일어나면 세포내의 spindle 손상을 인식하여 


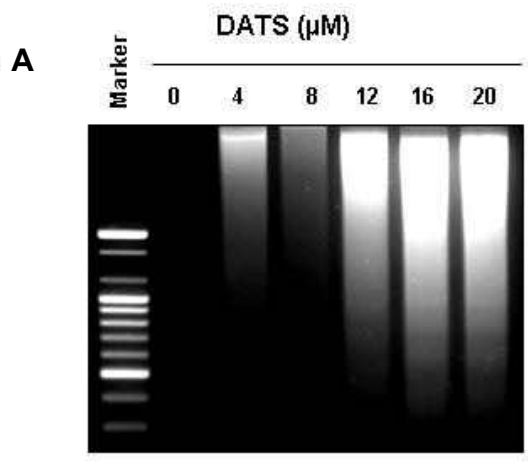

C
B

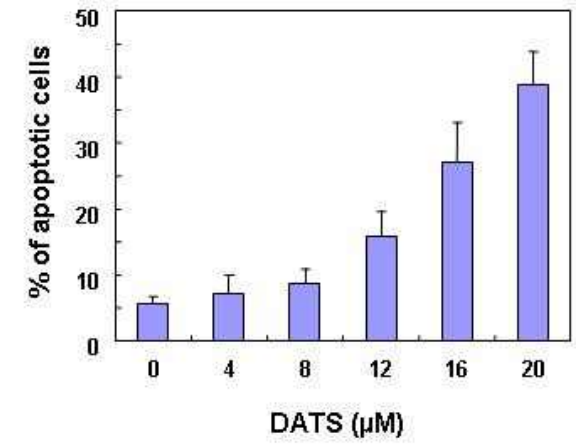

DATS $(20 \mu \mathrm{M})$

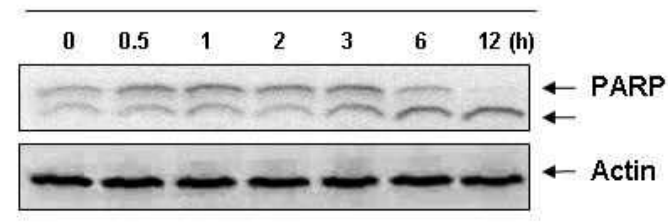

Fig. 2. Induction of apoptosis by DATS treatment in U937 cells. (A) After incubation with indicated concentrations of DATS for $12 \mathrm{hr}$, cells were collected and DNA was isolated. For the analysis of DNA fragmentation, the DNA was separated on $1.5 \%$ agarose gel electrophoresis and visualized under UV light after staining with EtBr. (B) For the quantification of apoptosis level, cells were collected and washed twice with cold PBS. Washed cells are stained with Annexin V-FITC and analyzed by flow cytometry. The results are expressed as the mean \pm SD of three independent experiments. (C) After incubation with DATS $(20 \mu \mathrm{M})$ for the indicated times, cells were lysed and then cellular proteins were separated by SDS-polyacrylamide gels. Separated proteins in gels were transferred to nitrocellulose membranes and probed with anti-PARP antibody. Actin was used as an internal control.

mitotic exit을 저해하는 역할을 하는 spindle checkpoint의 활 성을 계속해서 유지하게 되고, 결과적으로 mitotic exit을 억제 하게 되어 mitotic arrest를 일으키게 된다[27]. 뿐만 아니라, $\mathrm{CDK} 1$ 은 anti-apoptotic 단백질인 Bcl-2의 인산화를 매개하여 미토콘드리아의 기능 장애를 일으키게 되고 결과적으로 caspase 단백질들을 활성화 시켜 apoptosis에 의한 세포죽음을 일으킨다고 알려져 있다[29]. U937 세포에 DATS를 처리할 경 우 apoptosis가 일어나기 전에 G2/M arrest가 일어남을 Fig. $1 \mathrm{~B}$ 를 통해 확인하였지만, 이러한 DATS에 의한 $\mathrm{G} 2 / \mathrm{M}$ arrest 가 mitotic arrest에 의한 것인지의 여부를 조사하기 위하여, mitotic arrest와 관련된 단백질 발현 변화를 조사하였다. DATS 처리 시간의 증가에 따라 CDK1과 cyclin B1의 발현이 매우 증가되었으며(Fig. 3), 이는 DATS에 의한 G2/M arrest는 $\mathrm{G} 2$ arrest가 아닌 mitotic arrest일 가능성을 보여주는 것이다. Mitotic arrest가 일어났을 때 나타나는 또 다른 현상 중의 하나 가 histone $\mathrm{H} 3$ 단백질의 10 번 serine기의 인산화 현상인데[3, 27], DATS 처리 후 6시간 이후에 histone $\mathrm{H} 3$ 의 인산화가 극단 적으로 증가되었다(Fig. 3). 따라서 DATS에 의한 U937세포의 증식 억제효과는 G2 arrest가 아닌 mitotic arrest와 관련이 있 음을 알 수 있었다.
DATS $(20 \mu \mathrm{M})$

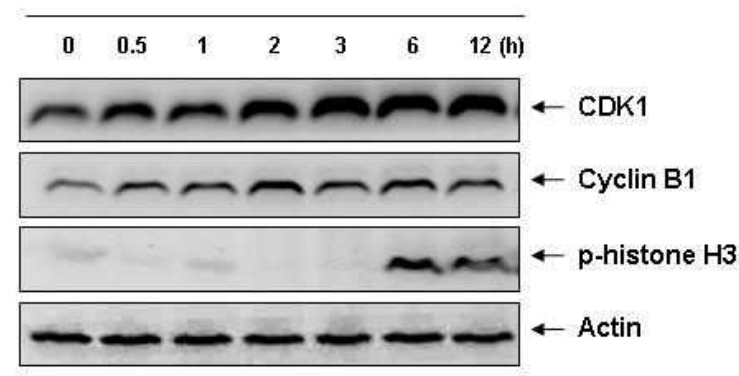

Fig. 3. Induction of mitotic markers by DATS treatment in U937 cells. After incubation with DATS $(20 \mu \mathrm{M})$ for the indicated times, cells were lysed and then cellular proteins were separated by SDS-polyacrylamide gels. Separated proteins in gels were transferred to nitrocellulose membranes and probed with the indicated antibodies. Actin was used as an internal control.

DATS 처리에 의한 ROS 생성이 apoptosis와 mitotic arrest에 미치는 영향

ROS는 세포의 증식과 분화, apoptosis와 같은 다양한 세포 의 기능과 밀접한 관련이 있는 것으로 알려져 있다. 이러한 ROS는 superoxide anion, singlet $\mathrm{O}_{2}, \mathrm{H}_{2} \mathrm{O}_{2}$ 등을 포함하며 UV, 
A

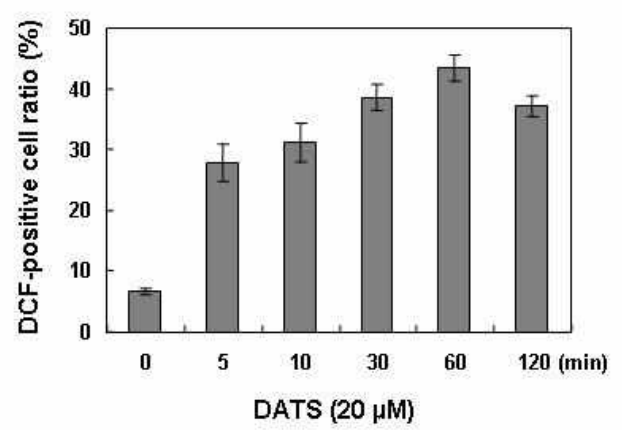

B

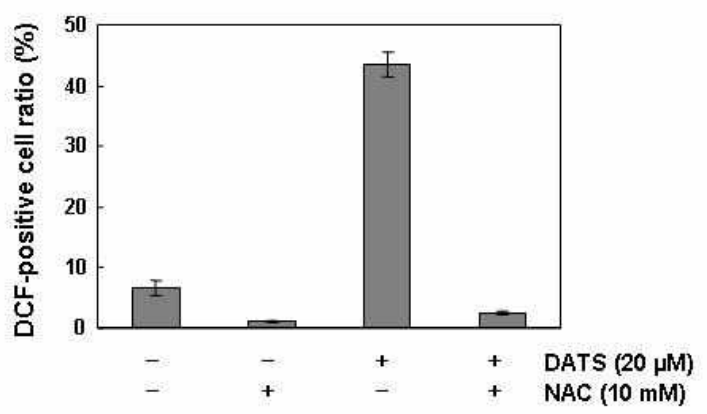

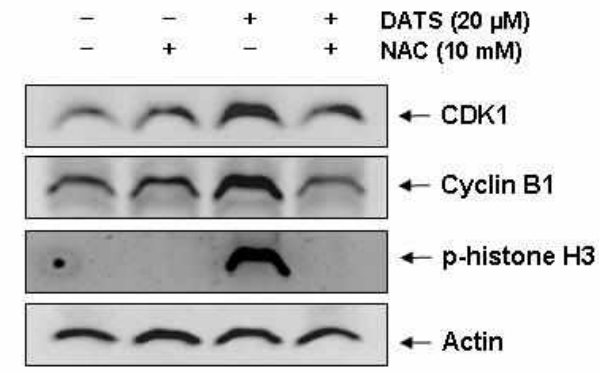

D

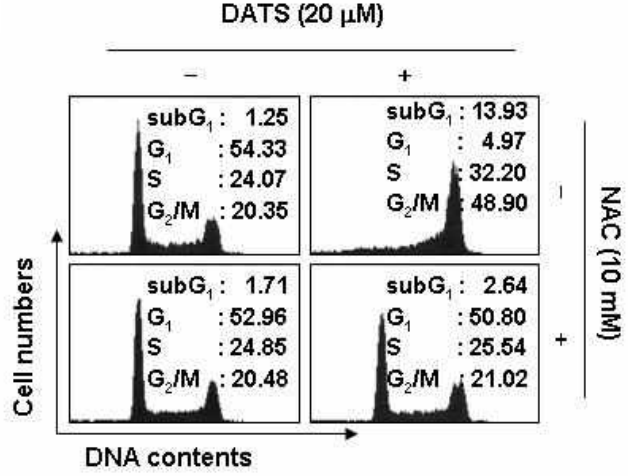

Fig. 4. Inhibition of apoptosis and mitotic arrest by pretreatment with NAC in DATS-treated U937 cells. (A) After incubation with DATS $(20 \mu \mathrm{M})$ for various periods or (B) pretreatment with $10 \mathrm{mM} \mathrm{NAC}$ for $1 \mathrm{hr}$ before being exposed to $20 \mu \mathrm{M}$ DATS for $1 \mathrm{hr}$, cells were stained with DCFDA for $30 \mathrm{~min}$ and collected. FACS analysis was used to assess the intracellular accumulation of ROS. The results are expressed as the mean $\pm S D$ of three independent experiments. (C) The cells grown under the same condition as (B) were lysed and then cellular proteins were separated by SDS-polyacrylamide gels. Separated proteins in gels were transferred to nitrocellulose membranes and probed with the specific antibodies. Actin was used as an internal control. (D) The cell cycle distribution of cells grown under the same condition as (B) was analyzed by flow cytometry. The results are expressed as the mean $\pm \mathrm{SD}$ of two independent experiments.

inflammatory cytokine, ionizing radiation, 다양한 항암활성 화합물 등과 같은 요인에 의해 생성되기도 하고 대사과정 중 미토콘드리아 등에 의해서도 생성될 수 있다. 일반적인 대사 과정 중에 생성되는 ROS는 자연스러운 현상이지만 여러 가지 자극에 의한 ROS의 과도한 생성은 cell cycle arrest와 apoptosis를 유도하는 핵심적인 역할을 한다[2, 7, 15, 22]. 아울러 최 근 연구에 의하면 ROS의 과도한 축적은 DNA와 같은 거대분 자들을 파괴하여 $\mathrm{G} 2 / \mathrm{M}$ arrest를 일으킨다고 알려져 있으며 $[12,30]$, 미토콘드리아 막의 투과성을 높이게 되어 세포질로 cytochrome $c$ 와 같은 caspase 단백질들의 활성화를 유도하는 인자를 유출하여 intrinsic apoptotic pathway를 활성화시키기 도 한다[23, 28]. 따라서 DATS에 의해 유도된 mitotic arrest와 apoptosis가 ROS의 생성과 연관되어 있는지 확인한 결과, Fig. $4 \mathrm{~A}$ 에 나타낸 바와 같이 DATS 처리 5 분 이내에 ROS 생성이 급격히 증가하였고 60 분경 최대를 보였다. 이렇게 생성된 $\mathrm{ROS}$ 가 세포증식에 어떠한 역할을 하는지 알아보기 위하여 ROS scavenger를 적용하여 보았다. ROS scavenger인 NAC를 DATS 처리 1 시간 선처리할 경우 세포 내 ROS 양이 정상세포 수준으로 돌아오는 것을 관찰할 수 있었으며, DATS 단독 처리
시 증가되었던 $\mathrm{CDK} 1$ 과 cyclin $\mathrm{B} 1$ 의 발현과 histone $\mathrm{H} 3$ 의 인산 화가 대조군 수준으로 억제되었다(Fig. 4B, 4C). 또한 flow cytometer를 통한 세포주기 분석에 의해서도 DATS 처리에 의해 증가되었던 $\mathrm{G} 2 / \mathrm{M}$ arrest와 sub-G1의 빈도가 NAC를 1시간 선처리하고 DATS를 처리한 군에서 대조군 수준과 유사함을 확인하였다(Fig. 4D).

이상의 결과들에서 DATS에 의한 U937 세포의 증식억제는 apoptosis에 의한 직접적인 세포의 죽음과 CDK1 및 cyclin B1의 발현 증가와 histone $\mathrm{H} 3$ 의 인산화에 따른 mitotic arrest 와 관련이 있음을 알 수 있었다. 또한 본 연구의 결과는U937 세포에서 DATS에 의한 ROS 생성이 apoptosis와 mitotic arrest를 일으키는데 초기 인자로서 결정적인 작용을 한다는 것 을 의미한다.

\section{감사의 글}

본 연구는 농촌진흥청 공동연구사업(\#7-19-42) 및 지식경제 부 · 부산광역시 지원 지역혁신센터사업(RIC08-06-07) 동의대 학교 Blue-Bio 소재개발 및 실용화 지원센터의 지원으로 이루 
어졌습니다.

\section{References}

1. Abramson, N. and Melton, B. 2000. Leukocytosis: basics of clinical assessment. Am Fam Physician 62, 2053-2060.

2. Barzilai, A. and Yamamoto, K. 2004. DNA damage responses to oxidative stress. DNA Repair (Amst) 3, 1109-1115.

3. Blagosklonny, M. V. 2007. Mitotic arrest and cell fate: why and how mitotic inhibition of transcription drives mutually exclusive events. Cell Cycle 6, 70-74.

4. Chen, M., Li, B., Zhao, X., Zuo, H., He, X., Li, Z., Liu, X. and Chen, L. 2012. Effect of diallyl trisulfide derivatives on the induction of apoptosis in human prostate cancer PC-3 cells. Mol Cell Biochem 363, 75-84.

5. Choi, Y. H. and Park, H. S. 2012. Apoptosis induction of U937 human leukemia cells by diallyl trisulfide induces through generation of reactive oxygen species. J Biomed SCi $19,50$.

6. Cline, M. J. 1994. The molecular basis of leukemia. $N$ Engl $J$ Med 330, 328-336.

7. D'Autréaux, B. and Toledano, M. B. 2007. ROS as signalling molecules: mechanisms that generate specificity in ROS homeostasis. Nat Rev Mol Cell Biol 8, 813-824.

8. Dalton, W. B., Nandan, M. O., Moore, R. T. and Yang, V. W. 2007. Human cancer cells commonly acquire DNA damage during mitotic arrest. Cancer Res 67, 11487-11492.

9. Elmore, S. 2007. Apoptosis: a review of programmed cell death. Toxicol Pathol 35, 495-516.

10. Gayathri, R., Gunadharini, D. N., Arunkumar, A., Senthilkumar, K., Krishnamoorthy, G., Banudevi, S., Vignesh, R. C. and Arunakaran, J. 2009. Effects of diallyl disulfide (DADS) on expression of apoptosis associated proteins in androgen independent human prostate cancer cells (PC-3). Mol Cell Biochem 320, 197-203.

11. Gilliland, D. G., Jordan, C. T. and Felix, C. A. 2004. The molecular basis of leukemia. Hematology Am Soc Hematol Educ Program 2004, 80-97.

12. Hseu, Y. C., Lee, M. S., Wu, C. R., Cho, H. J., Lin, K. Y., Lai, G. H., Wang, S. Y., Kuo, Y. H., Kumar, K. J. and Yang, H. L. 2012. The chalcone flavokawain B induces G2/M cell-cycle arrest and apoptosis in human oral carcinoma HSC-3 cells through the intracellular ROS generation and downregulation of the Akt/p38 MAPK signaling pathway. $J$ Agric Food Chem 60, 2385-2397.

13. Liu, K. L., Chen, H. W., Wang, R. Y., Lei, Y. P., Sheen, L. Y. and Lii, C. K. 2006. DATS reduces LPS-induced iNOS expression, NO production, oxidative stress, and NF-kappaB activation in RAW 264.7 macrophages. $J$ Agric Food Chem 54, 3472-3478.

14. Malumbres, M and Barbacid, M. 2009. Cell cycle, CDKs and cancer: a changing paradigm. Nat Rev Cancer 9, 153-166.

15. Matés, J. M., Segura, J. A., Alonso, F. J. and Márquez, J. 2012. Oxidative stress in apoptosis and cancer: an update. Arch Toxicol 86, 1649-1665.
16. Mollinedo, F. and Gajate, C. 2003. Microtubules, microtubule-interfering agents and apoptosis. Apoptosis 8, 413-450.

17. Schafer, K. A. 1998. The cell cycle: a review. Vet Pathol 35, 461-478.

18. Shin, D. Y., Kim, G. Y., Lee, J. H., Choi, B. T., Yoo, Y. H. and Choi, Y. H. 2012. Apoptosis induction of human prostate carcinoma DU145 cells by diallyl disulfide via modulation of JNK and PI3K/AKT signaling pathways. Int J Mol Sci 13, 14158-14171.

19. Terrano, D. T., Upreti, M. and Chambers, T. C. 2010. Cyclin-dependent kinase 1-mediated Bcl-xL/Bcl-2 phosphorylation acts as a functional link coupling mitotic arrest and apoptosis. Mol Cell Biol 30, 640-656.

20. Vermeulen, K., Van Bockstaele, D. R. and Berneman, Z. N. 2003. The cell cycle: a review of regulation, deregulation and therapeutic targets in cancer. Cell Prolif 36, 131-149.

21. Wang, H. C., Yang, J. H., Hsieh, S. C. and Sheen, L. Y. 2010. Allyl sulfides inhibit cell growth of skin cancer cells through induction of DNA damage mediated $\mathrm{G} 2 / \mathrm{M}$ arrest and apoptosis. J Agric Food Chem 58, 7096-7103.

22. Wang, J. and Yi, J. 2008. Cancer cell killing via ROS: to increase or decrease, that is the question. Cancer Biol Ther 7, 1875-1884.

23. Wang, J., Yu, Y., Hashimoto, F., Sakata, Y., Fujii, M. and Hou, D. X. 2004. Baicalein induces apoptosis through ROS-mediated mitochondrial dysfunction pathway in HL-60 cells. Int J Mol Med 14, 627-632.

24. Wong, R. S. 2011. Apoptosis in cancer: from pathogenesis to treatment. J Exp Clin Cancer Res 30, 87.

25. Wu, C. C., Chung, J. G., Tsai, S. J., Yang, J. H. and Sheen, L. Y. 2004. Differential effects of allyl sulfides from garlic essential oil on cell cycle regulation in human liver tumor cells. Food Chem Toxicol 42, 1937-1947.

26. Wu, X. J., Hu, Y., Lamy, E. and Mersch-Sundermann, V. 2009. Apoptosis induction in human lung adenocarcinoma cells by oil-soluble allyl sulfides: triggers, pathways, and modulators. Environ Mol Mutagen 50, 266-275.

27. Yamada, H. Y. and Gorbsky, G. J. 2006. Spindle checkpoint function and cellular sensitivity to antimitotic drugs. $\mathrm{Mol}$ Cancer Ther 5, 2963-2969.

28. Yang, J., Xiao, Y. L., He, X. R., Qiu, G. F. and Hu, X. M. 2010. Aesculetin-induced apoptosis through a ROS-mediated mitochondrial dysfunction pathway in human cervical cancer cells. J Asian Nat Prod Res 12, 185-193.

29. Yang, J. S., Hour, M. J., Huang, W. W., Lin, K. L., Kuo, S. C. and Chung, J. G. 2010. MJ-29 inhibits tubulin polymerization, induces mitotic arrest, and triggers apoptosis via cyclin-dependent kinase 1-mediated Bcl-2 phosphorylation in human leukemia U937 cells. J Pharmacol Exp Ther 334, $477-488$.

30. Yogosawa, S., Yamada, Y., Yasuda, S., Sun, Q., Takizawa, $\mathrm{K}$ and Sakai, T. 2012. Dehydrozingerone, a structural analogue of curcumin, induces cell-cycle arrest at the G2/M phase and accumulates intracellular ROS in HT-29 human colon cancer cells. J Nat Prod 75, 2088-2093. 
초록 : U937 인체혈구암세포에서 diallyl trisulfide에 의한 mitotic arrest와 apoptosis 유발

박현수 ${ }^{1} \cdot$ 이준혁 ${ }^{2} \cdot$ 손병일 $^{3} \cdot$ 최병태 ${ }^{1} \cdot$ 최영현 ${ }^{45_{*}}$

( ${ }^{1}$ 부산대학교 한의학전문대학원, ${ }^{2}$ 특허청 화학생명공학심사국 생명공학심사과, 동의대학교 ${ }^{3} \mathrm{Blue-Bio} \mathrm{소재}$ 개발 및 실용화 지원 센터, ${ }^{4}$ 항노화연구소 및 ${ }^{5}$ 한의과대학 생화학교실)

본 연구에서는 마늘에서 유래된 생리활성 물질인 diallyl trisulfide (DATS) 처리에 따른 U937 인체혈구암세포 의 증식억제가 apoptosis 및 cell cycle arrest 유발과 관련이 있는지 조사하였다. U937 세포증식은 DATS에 의해 농도 및 시간 의존적으로 감소함을 확인 하였고, 이는 apoptosis에 의한 직접적인 세포죽음과 CDK1 및 cyclin B1의 발현 증가 및 histone $\mathrm{H} 3$ 의 인산화와 연관된 mitotic arrest와 관련이 있음을 알 수 있었다. 또한 DATS 처리 초기에 reactive oxygen species (ROS)의 생성이 매우 증가되었으나, ROS scavenger (N-acetyl-1-cysteine)에 의한 인위적 ROS 생성의 억제는 DATS에 의한 apoptosis 및 mitotic arrest를 완벽하게 차단시켰다. 이는 U937 세포에 서 DATS에 의해 유도된 apoptosis 및 mitotic arrest가 ROS에 의해 매개된다는 것을 의미하며, 본 연구의 결과는 DATS가 인체혈구암세포에서 세포증식억제와 관련된 항암기전을 이해할 수 있는 기초자료로서 매우 유용하게 사용될 것이라 생각된다. 